\title{
Lower Gingival Squamous Cell Carcinoma
}

National Cancer Institute

\section{Source}

National Cancer Institute. Lower Gingival Squamous Cell Carcinoma. NCI Thesaurus.

Code C8171.

A squamous cell carcinoma of the oral cavity that arises from the lower gingiva. 